\title{
Librarian in the underground
} What academic libraries can learn from DIY culture

\begin{abstract}
See yourself as the pilot of an elaborate spacecraft in unfamiliar territory. If you freeze, tense up, refuse to look at what is in front of you, you will crack up the ship. On the other hand, credulity and uncritical receptivity are almost as dangerous.
\end{abstract}

—William S. Burroughs, Ab Pook Is Here

A cademic library professionals are now in uncharted territory. We're hurtling through unfamiliar, rapidly shifting landscapes. Information storage and retrieval, scholarly publishing, information literacy: everything's changing on a daily basis. Get hung up on any one thing, and you're already working in the past. Allow yourself to be overwhelmed and you're paralyzed.

It's a feeling not unfamiliar to the independent musician. You're on the road in between shows, it's the middle of the night, and you've got no money for anything but gas. So you spend the night in a parking garage in Savannah and head out the next morning to a gig that's a series of question marks. Did the club owner do any promotion? Will they honor your piddling guarantee? Will the sound guy be an utter jerk? Will the mics be properly grounded or are you going to get a mini-tazer jolt right in the face every time you lean in to address the audience?

Believe it or not, librarians can learn a lot from the ragtag legion of troubadours crisscrossing North America every day. We've walked in both pairs of shoes, and we're convinced. We can sum it up in three letters: DIY.

\section{So what is DIY? DO IT YOURSELF!}

Unless you've got a rich uncle or write the kind of music that's going to end up playing in a Gap changing room you're going to need to bust your hump as a musician. You don't play a few club gigs, get discovered and signed, and ease into a life of destroying expensive hotel rooms. You're going to haul your own amps, replace your own strings, drive your own vehicle into the ground, eat \$1 meals, sweat it out under broken lights at clubs with all of three people in the audience, play on the same grimy basement floor you'll be sleeping on later.

And it's awesome. Because in addition to meeting great people and forming lifelong friendships, you'll get to see faces light up in excitement, hear great music, visit amazing places, and generally take part in a nonstop adventure, satisfied in the knowledge that you were willing to do it yourself.

That's DIY in a nutshell. You've got something to do, and you make it happen. You.

Solomon Blaylock is section supervisor-reserves, email: sblaylock@library.rochester.edu, and Declan Ryan is library assistant, email: dryan@library.rochester.edu, at the University of Rochester River Campus Libraries

(ㄷ) 2017 Solomon Blaylock and Declan Ryan 
Make it happen. DIY, though, isn't some sort of Randian, look-out-for-number-one scene -independent musicians all over the world embrace an ethic of self-reliance undergirded by inclusivity and integrity that creates tightknit communities in cities, suburbs, and rural outposts alike. You've just got to be willing to make it happen.

We believe this spirit is just what's needed in the 21st-century academic library. We've all heard the line at a party or even from a skeptical faculty member or student: What do we need libraries for now that we have the Internet? ${ }^{1}$ We know good and well that we do a hell of a lot of stuff that nobody knows how to do better than us. Who's better than us at digital asset management; navigating and putting to effective use an array of electronic and physical resources; ensuring that these resources are available next month, year, decade; getting academic work done? This is what we do. But just like with music, doing is only half the battle. To extend a metaphor, nobody's going to do our promotion for us, nobody's going to pass out our flyers, book our tour dates, or get the crowds into the venues. We've got to meet people where they are and show them what we can do for them. It's up to us.

For independent musicians who want to get the word out about their music, the timetested method is the tour. For most of us this has meant setting each show up in each town by means of several calls, emails, and texts; working to do what promotion you can from a distance; hustling your own merchandise after each show; etc. It's a lot of work, but how else would anyone know about you or what you do? The same goes for those of us in libraries. Forget sitting behind a desk all day and waiting for people to come to you. You're going to be waiting a long time. Like, forever. Outreach is an indispensable part of work in the modern academic library, and not just for traditional reference librarians. The Access Services department at Rutgers' George F. Smith Library of the Health Sciences has provided a good example of how traditionally passive library services can be brought front and center by means of popup programming both within and without the library building. ${ }^{2}$ We have to invest the time and energy into these kinds of activities if we expect our patrons to know what we can do for them.

The fundamental widening of the gateways for information search have obvious parallels in the modern models of entertainment distribution. As transactional models of sharing content (movie and live event tickets) have been upended by subscriptionbased models (Netflix, Spotify, etc), the old gatekeepers of this content find that they must compete with a broad spectrum of services for their prospective patrons' time and attention. We know that what we do is fundamentally better than a packaged or automated alternative for a number of reasons-the trick is getting everyone else to understand the reasons why this is true. The only way to do this is to bring the message to the people.

\section{All in together}

Smart and energetic promotion are important to spreading any message, but they should always supplement the cultivation of real relationships. DIY communities are established and maintained through oneon-one interactions - an offer of a couch to crash on after a show, a local printing hookup, a friend of a friend whose band can support a bill. Similarly there's no substitute for face-to-face interaction in libraries, whether we're providing research support, working on a grant proposal, or soliciting feedback. The personal relationships we form as individual members of an organization grow and overlap to form a network of colleagues and patrons with whom we collaborate in order to support the teaching and learning missions of our parent institutions.

Our communities must be inclusive. This is as imperative for the independent musician as for the modern library professional. The principles we embody ${ }^{3}$ include a commitment to diverse representation. This is more than just providing a space in which all 
participants are treated equally. Neutrality in the face of inequality guarantees the maintenance of the status quo. ${ }^{4}$ We have to make room for voices that have been and continue to be marginalized. In a DIY music space, this involves making real, ongoing efforts at booking bands from diverse backgrounds 5 and ensuring that vulnerable community members are physically safe at shows. ${ }^{6}$ In libraries it means actively working to diversify the members of our profession so that we're properly representing the populations we serve. It means reworking our spaces and programming so that traditionally marginalized community members feel a genuine sense of belonging and participation.

Make no mistake, we live in times when these inclusive values are under attack. ${ }^{7}$ We cannot afford simply to affirm often toothless "commitments to diversity." We need action. Last year Katy Mathuews of Ohio University's Alden Library issued a direct challenge to those of us in the library profession to put our money where our mouth is: "Often...libraries choose to express the commitment to diversity and social justice through diversity initiatives that are too simplistic to achieve true social justice ideals." Mathuews recommends re-envisioning standard library functions like IL, research services, and disseminating scholarship such that they are built from the ground up with social justice in mind.

This work has to be done, and nobody's going to do it for us. We've got to do it ourselves. When the work feels too exhausting, picture the world that the troglodytes who would try to stop us would realize in our absence. A tragic blandscape of banal daytime television; a slog through traffic-prioritized digital fiefdoms under constant surveillance; an unending suburban savannah of pavedover shopping plazas and drive-thrus, each diversion calculated meticulously to appeal only to the lowest-common denominator.

\section{Roll with the punches}

Bringing things back to where we started, maybe the most important thing that we in libraries can learn from independent musi- cians is the ability to deal with sudden and dramatic change, on scales small and large.

A house show gets cancelled at the last minute, the bass player's amp shorts out, the opening act doesn't bring a drum kit, mixing the album is taking twice as long as you planned. You can get all worked up about it or you can correct course and keep moving forward. As Swans alum Thor Harris observes: "Whining is tour cancer. If something is wrong fix it or shut the ... up." Inconveniences and the way we reroute our days around them are the forge of temperament.

But there are meso- and macroscales to this upheaval, as well. The crash-and-burn of the recorded music industry at the start of the millennium represents a mesoscale change that DIY'ers have found new ways to navigate. On the macroscale, the generational shift away from rock music in general presents new and larger challenges that we believe can only be faced with a deep commitment to inclusiveness and artistry. The fractal web of troubles that faces us in the ivory tower is geometrically similar to the one our DIY brethren must brave, even if the specifics are different.

Nobody comes to your reference desk anymore? Get rid of it. But it's historically symbolic and has tremendous sentimental value. Cool. Take a picture of it, and then get rid of it. People haven't stopped doing academic work. If they're not picking up what we're putting down, then we need to rethink what we're putting down.

\section{So long, and thanks for all the shoes}

If this picture seems bleak, remember that the meteor that killed the dinosaurs also cleared the way for the evolution of large mammals (that's us). It's all really exciting. Everything that's going on right now-all the change, upheaval, revolution-provides us with the opportunity for inspired action at a time when it can really make a difference.

As the summer returns, thousands of young musicians are loading their only possessions of value into hundreds of dilapidated 
vans. They go forward knowing that the route will be fraught. Many are working without a net. There is little prospect of fortune or fame-often there's barely prospect of a place to shower. But regardless of doubts or reservations, the highway stretches to the horizon all the same. And while we may not have the same romantic backdrop or narrative here in the academy, we really ought to learn a thing or two from those indigent but intrepid souls who find a way to make it work.

\section{Notes}

1. Steve Denning, "Do We Need Libraries?" Forbes (April 28, 2015), www.forbes.com /sites/stevedenning/2015/04/28/do-we-need -libraries/\#718303616cd7 (accessed February 2, 2016).

2. Yini Zhu, "Teach and Tell: Access Services' Role in the Big Picture," https:// www.libraries.rutgers.edu/rul/staff/training /sotl_2015/Teach_and_Tell.pdf (accessed February 2, 2016).

3. ALA, "Key Action Areas," www.ala.org /aboutala/missionpriorities/keyactionareas (accessed February 2, 2016).
4. Özlem Sensoy \& Robin DiAngelo, "Respect Differences? Challenging the Common Guidelines in Social Justice Education," Democracy E Education 22, no. 2 (2014): 1-10.

5. Dominic Posinelli, "Soundcloud Changed My Life: An Introduction to DIY Music," The Michigan Daily (November 30, 2016), https://www.michigandaily.com /section/arts/copy-diy-music-lead (accessed February 2, 2016).

6. Nina Mashurova, "Strategies for Keeping Our DIY Venues Safer," adhoc (September 14, 2016), http://adhoc.fm/post/shows-cantkeep-us-safe-they-can-be-safer/ (accessed February 2, 2016).

7. Benjamin Freed, "'Alt-Right' Trolls are Targeting DC's DIY Music Houses," Washingtonian (December 19, 2016), https:// www.washingtonian.com/2016/12/19/alt -right-trolls-targeting-dcs-diy-music-houses / (accessed February 2, 2016).

8. Katy Mathuews, "Moving Beyond Diversity to Social Justice: A Call to Action for Academic Libraries," Progressive Librarian (44): 6-27.

9. http://monofonuspress.com/news /thor-harris-on-how-to-tour-in-a-band-or -whatever (accessed February 3, 2016).

\section{("Doing technology," continues from page 306)}

Ultimately, these academic-public library collaborations can be fulfilling and engaging, and, most importantly, they can open new directions to support the academic institution's commitment to student success, diversity, and community engagement.

\section{Acknowledgement}

We would like to acknowledge our partner-Fresno County Public Library-for being such great hosts and supporters of this project, and particularly Daniel Ng and Lisa Lindsay.

We also like to extend our thanks to Fresno State's President Joseph I. Castro and the Touch the Community project coordinators, Alex Gallo, Chris Florentino, and Sherri Fisk, for making this possible; to the Henry Madden Library colleagues who have been supportive, Dave Tyckoson, Peter McDonald, Glenda Harada, and Amanda Dinscore; and finally thanks to all of our student ambassadors who embedded themselves into the communities to support Fresno.

\section{Notes}

1. Elaine Carey and Raymond Pun, "Doing History: A teaching collaboration between St. John's University and the New York Public Library," CERL News 73, no. 3 (2012).

2. D. Walters, "Fresno has high poverty concentration, national study finds," Sacramento Bee, August 14, 2015, see www.sacbee. $\mathrm{com} /$ news/politics-government/capitol-alert /article31113221.html.

3. See California's Digital Divide, June 2013, www.ppic.org/main/publication_show. asp?i=263. 